\title{
Seismic acquisition and rotary drilling study to a Hydroelectric Generating Plant (HGP) building in Pindaíba river.
}

Thiago Lima Mendes, Marcelo Pellicano Falleiros, Moara Maria O. de Matos, Welitom Rodrigues Borges - University of Brasília; Carlos Gonzalo Larrosa, Rafael Pereira Felix - L\&S Consultoria.

\section{Copyright 2019, SBGf - Sociedade Brasileira de Geofísica}

This paper was prepared for presentation during the $16^{\text {th }}$ International Congress of the Brazilian Geophysical Society held in Rio de Janeiro, Brazil, 19-22 August 2019.

Contents of this paper were reviewed by the Technical Committee of the $16^{\text {th }}$ International Congress of the Brazilian Geophysical Society and do not necessarily represent any position of the SBGf, its officers or members. Electronic reproduction or storage of any part of this paper for commercial purposes without the written consent of the Brazilian Geophysical Society is prohibited.

\section{Abstract}

The work describes the activities and results of seismic acquisition and rotary drilling, carried out in a region planned for the installation of a Hydroelectric Generating Plant (HPG). The objective of seismic acquisitions was to identify the thicknesses and depths of geotechnical layers. The variations of velocities identified in the seismograms added to the probe data allowed the delimitation of layers of low compaction materials (soil, with $P$ wave velocity below $1500 \mathrm{~m} / \mathrm{s}$ ), medium compaction materials (Rock Weathered and easy to disaggregate, with speeds between 1500 and $2300 \mathrm{~m} / \mathrm{s}$ ), and high compaction and mechanical strength materials (non-weathered rock or poorly tempered, with speeds above $2300 \mathrm{~m} / \mathrm{s}$ ). The results showed that the refraction seismic was efficient in the delimitation of the layers up to the depth of 35 meters.

\section{Introduction}

The construction of a hydroelectric generating plant requires a series of studies regarding the surface and subsurface of the site. Nevertheless, geological information, such as soil thickness and depth of the rock basement, is valuable information to minimize the risks related to this work. Therefore, the objective of this paper is the use of direct and indirect sampling methods to characterize layer thickness, according to its degree of compaction and mechanical strength.

The study area comprises the region belonging to the Ribierão Pindaíba river basin, which in turn is located in the southwest region of Goiás between the municipalities of Rio Verde and Montividiu. According to CPRM's (2002) map of the Southwest of the area, four different lithologies occur within the Pindaíba basin (Figure 1): at the base, with Cretaceous age, there is the Alkali Province of the South of Goiás (K入1), which, in brief words, is an alkaline basaltic effusion; above, the Adamantina Formation (Kba), which can be described as a very fine to fine sandstone interspersed with silicon layers and conglomerate sandstone lenses (Soares et al., 1980); at the top, the quaternary coverings involve the rocks, the oldest being the undifferentiated sandy cover - fine to coarse sand, locally silty-clayey and gravel (QPi) - and the newest alluvium (QHa) - sand, quartz sand, gravel, silt, clay - where the Pindaíba stream runs

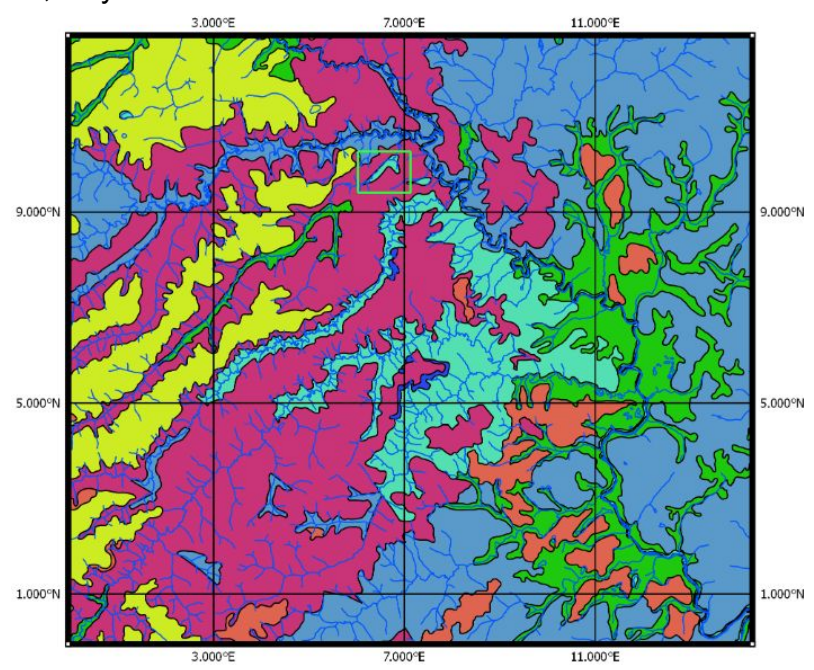

Legend
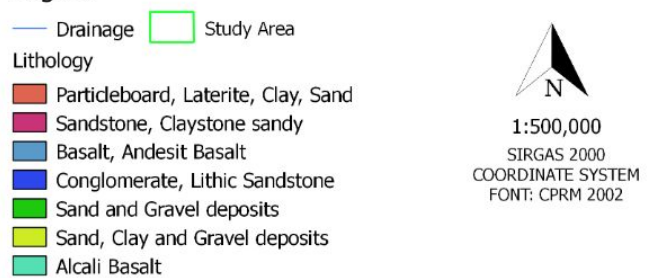

Sand, Clay and Gravel deposits Alcali Basalt

Figure 1: Geological map of the studied area.

The refractive seismic method makes use of the principle that a wave when traversing different means, can change the direction and its path according to the speed contrast between the layers - Snell's Law (Reynolds, 1997).

$$
\sin \left(i_{c}\right)=\frac{V_{1}}{V_{2}}
$$

Equation 1 - Snell's Law.

And according to Figure 3, it is the angle that defines the direction of propagation of the direct wave, the velocity of the upper layer and the velocity of the lower layer.

Therefore, the use of indirect methods in the evaluation of decision making is fundamental to bring subsurface information. The refractive seismic is efficient in terms of 
SEISMIC ACQUISITION AND ROTARY DRILLING STUDY TO A HYDROELECTRIC GENERATING PLANT (HGP) BUILDING IN PINDAíBA RIVER.

velocity contrasts and has as prerogative that the bottom layer always has higher propagation velocity than the top layer. In the study area, the lithologies have a high variation of density, generating a substantial change in the speed of the $\mathrm{P}$ wave. Also, direct sampling through rotary drilling served as a fundamental tool to corroborate the seismic data, associating the depth of the interfaces between soil, rock and saprolite with the seismic change rate interface.

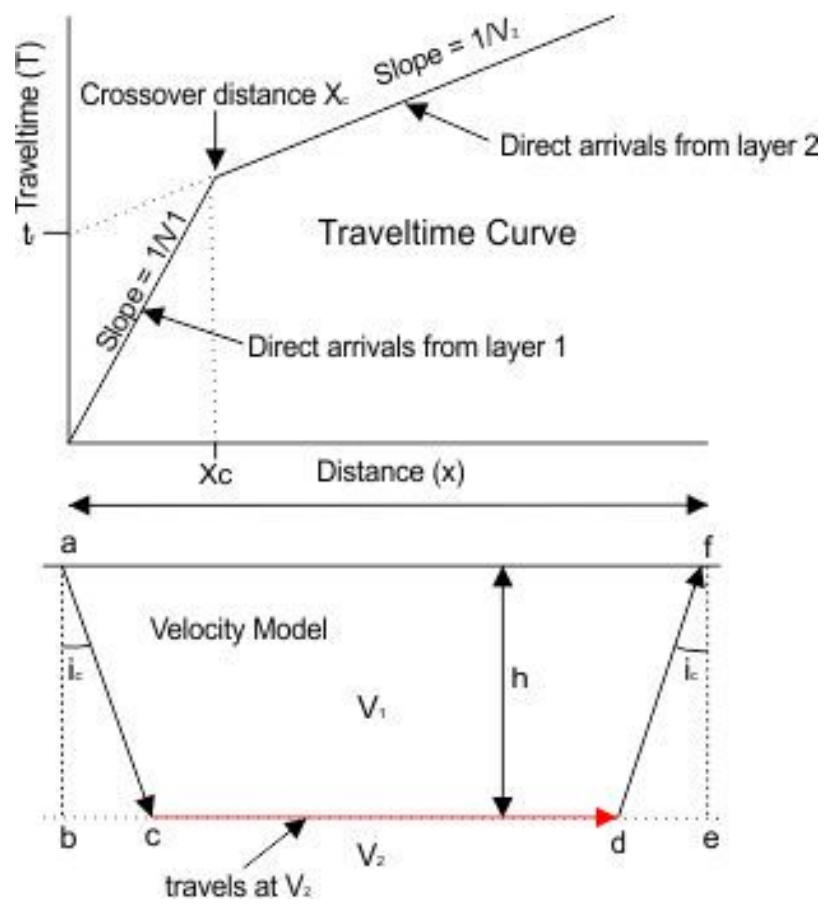

Figure 2 - Mathematical models of refraction (extracted from the Seilmager program manual, appendix A).

\section{Method}

The acquisition of the seismic data was achieved through 5 lines, perpendicular to each other, being two lines with 600 meters in length and 3 with 100 meters in length and the spacing of 5 meters between the geophones to generate a higher resolution of the data. To support the experiment, the drilling holes were set at strategic points, intercepting different seismic lines.

The survey of shallow refraction seismic consists of the construction of a line composed of equidistant geophones, capable of capturing the signal of the seismic wave. The signal source is generated by hammer blow action piece on a metal surface. The equipment capable of converting the signal obtained by the geophones is GEODE, which produces a graph of the seismic waves as a function of time and distance (seismogram).

From the seismogram and considering Snell's Law, it is possible to calculate the depth $(h)$ of the interface between the layer of higher and lower velocity, that is, the refraction itself of the wave.

$$
h=\frac{1}{2} \sqrt{\frac{\left(V_{2}-V_{1}\right)}{\left(V_{2}+V_{1}\right)}} x_{c}
$$

Equation 2 - Depth (h) of the interface between the different velocity layers $\left(V_{1}\right.$ and $\left.V_{2}\right)$.

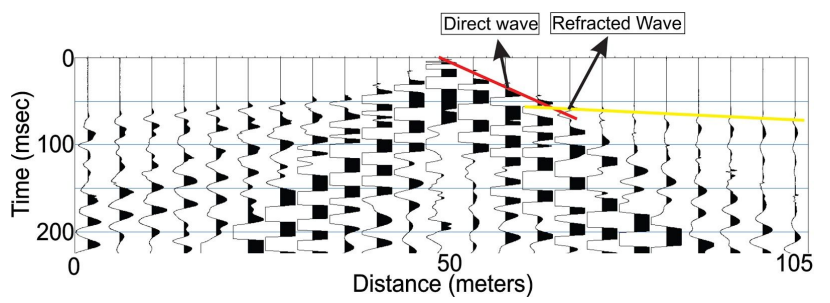

Figure 3 - Seismogram referring to the shot at the middle of the line $C$. The orange line refers to the refracted wave and the red line represents the direct wave.

In the case of two layers, the refracted wave is seen through the first arrivals, which generate a track with a smaller slope than the line produced by direct wave signals (first layer). As an example, Figure 3 shows the seismogram referring to the acquisition with the source at the beginning of line $\mathrm{C}$, being the red color the direct wave and the orange color refracted wave. In this way, the two-layer model is generated, which is used to elaborate on the seismic tomography model.



Figure 4: Location map of seismic lines and drilling holes.

\section{Results}

In all the acquisition lines it was possible to obtain a seismic tomography model, which results in a profile that presents the variations of the velocity of the $P$ wave as a function of distance and depth. Besides, four drilling holes, that intercept the acquisition lines, were sampled, integrating direct (borehole) and indirect (seismic) methodology.

Having the exact depth of the interfaces between soil and rock, it was possible to determine the velocity of the $P$ wave in the environment in question and finally generate a model whose layers are classified into types of dismantling. The first lower speed layer refers to excavatable materials (soil); the second layer (speed between 1500 and $2300 \mathrm{~m} / \mathrm{s}$ ) refers to the scarifiable materials (saprolite) and the third layer (speed above 
$2300 \mathrm{~m} / \mathrm{s}$ ) is equivalent to materials having a high degree of cohesion and extreme mechanical strength (rock).

Table 1: Relationship between legend of geotechnical models and layer information.

\begin{tabular}{|l|l|l|l|}
\hline Legend & $\begin{array}{l}\text { Seismic } \\
\text { Velocity } \\
(\mathrm{m} / \mathrm{s})\end{array}$ & Interpretation & Caracterization \\
\hline & $<1500$ & Soil & Excavable \\
\hline & $\begin{array}{l}1500- \\
2300\end{array}$ & Saprolite & Scarifiable \\
\hline & $>2300$ & Rock & Non-scarifiable \\
\hline
\end{tabular}

Once the values are defined, the velocity isolators are created in the media, depending on the categories of dismantling. In this way, the geotechnical model is generated, which consists of a profile with the thicknesses of the excavatable, scarifiable and non-scarifiable layers.
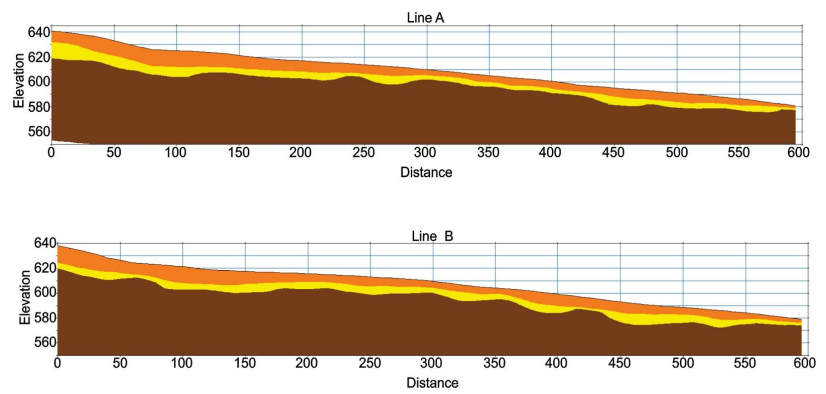

Figure 5: Geotechnical model for longitudinal lines (600 meters long).

Figure 5 demonstrates a similar pattern for the most extended lines, with the soil and saprolite thicker at the beginning of the line and a thinning of the same at the end of the profile. It is worth mentioning that the Pindaiba stream is approximately 10 meters away from the end of the lines causing the narrowing of the soil layer and saprolite.

The transversal lines have a similar character, with a soil thickness ranging from 8 to 12 meters and depth of the rock around 15 meters. Only line $\mathrm{C}$ has a thicker soil because it is higher than the other lines.
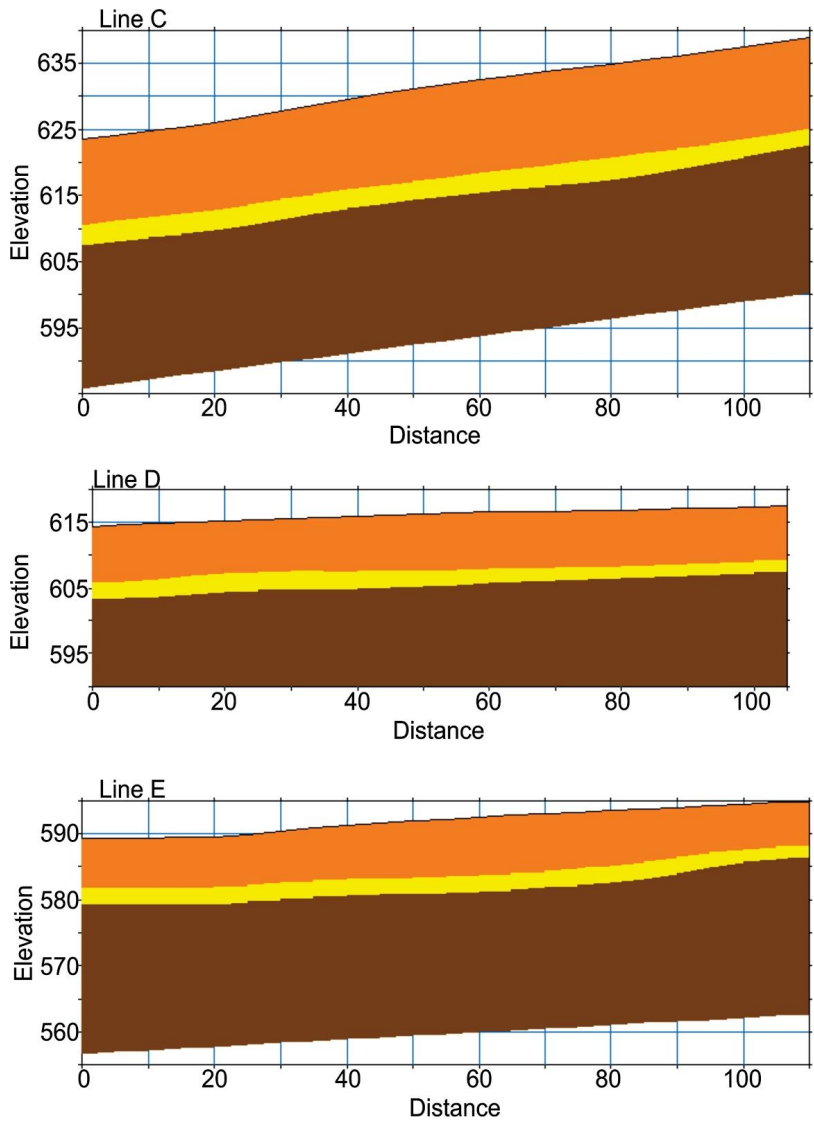

Figure 6: Geotechnical model for the transverse lines (100 meters in length).

\section{Conclusions}

The application of geophysical methods to geotechnical studies has been gaining popularity over time. Due to the difference between the layer of unconsolidated materials and a rock with a high degree of cohesion of the particles, the refractive seismic method has an excellent response to the study area. In addition, it is possible to generate a reaction in a faster time and at a lower cost, covering a larger area than using only survey information.

Finally, the geophysical methods used were efficient in the identification and (indirect) characterization of the classified layers in function of the degree of compaction of the material. Associated to the information of the survey, the geotechnical models have greater reliability. It is expected that the result will be of an auxiliary nature to reduce the costs of the $\mathrm{CGH}$ construction site Pindaíba 1.

\section{Acknowledgments}

The authors thank the companies Phygeo Jr and L \& S Consultoria for jointly establishing a geotechnical project. They also thank $L$ \& $S$ Consultoria for providing all the data of the rotary survey. Finally, the authors thank Professors Welitom Rodrigues Borges and Marcelo Peres Rocha for their guidance. 
SEISMIC ACQUISITION AND ROTARY DRILLING STUDY TO A HYDROELECTRIC GENERATING PLANT (HGP) BUILDING IN PINDAÍBA RIVER.

References

CPRM - Serviço Geológico do Brasil. "Descrição das unidades litoestratigráficas do Estado de Goiás e do Distrito Federal". 2002.

Kearey, P.; Brooks, M.; Hill, I. Livro: "An introduction to geophysical exploration". 2002, $3^{\circ}$ edição.

Manual SeisImager/2D ${ }^{\mathrm{TM}}$. 2009, versão 3.3.

Reynolds, J. M.; "An introduction to applied environmental geophysics” 1997.

FERNÁNDEZ, Bruno Picinin. Caracterização geológico-geotécnica de solos da Asa Sul a partir de métodos de aquisição sísmica, Brasília, Distrito Federal-Brasil. 2017.

RADAELLI, L. L.; CERELLO, L. Escavações. In: OLIVEIRA, A. M. S.; BRITO, S. N. A. Geologia de Engenharia. 6.ed. São Paulo: ABGE, 1998. 